\title{
UJI AKTIVITAS ANTIBAKTERI EKSTRAK DAUN SAPAT(MITRAGYNA SPECIOSA KORTH.) TERHADAP BAKTERI ESCHERICHIA COLI DAN STAPHYLOCOCCUS AUREUS
}

\author{
Leny Munawwarah*, Adam M. Ramadhan, Mirhansyah Ardana \\ Laboratorium Penelitian dan Pengembangan FARMAKA TROPIS Fakultas Farmasi, \\ Universitas Mulawaran, Samarinda, Kalimantan Timur \\ *email: lenymunawwarah1704@gmail.com
}

\begin{abstract}
ABSTRAK
Telah dilakukan penelitian tentang Uji Aktivitas Antibakteri Ekstrak Daun Sapat (Mitragyna speciosa Korth.) terhadap bakteri Eschericia coli dan Staphylococcus aureus. Penelitian ini bertujuan untuk mengidentifikasi golongan senyawa metabolit sekunder dan mengetahui aktivitas antibakteri ekstrak metanol daun sapat (Mitragyna speciosa Korth.) terhadap bakteri Escherichia coli dan Staphylococcus aureus. Identifikasi metabolit sekunder dilakukan dengan uji kualitatif. Pengujian aktivitas antibakteri dengan menggunakan metode difusi agar dengan konsentrasi uji 3\%, 6\%, 9\%, 12\%, 15\%, 18\%, 21\%, 24\%, $27 \%$ dan $30 \%$. Hasil identifikasi golongan senyawa metabolit sekunder terdapat senyawa alkaloid, saponin, tanin, fenolik dan steroid. Data hasil penelitian aktivitas antibakteri diukur dengan diameter zona bunuh ekstrak metanol daun sapat. Hasil penelitian menunjukkan bahwa ekstrak metanol daun sapat memiliki aktivitas dalam membunuh pertumbuhan bakteri uji. Konsentrasi efektif ekstrak metanol daun sapat untuk membunuh bakteri Escherichia coli dan Staphylococcus aureus yaitu pada konsentrasi $24 \%$.
\end{abstract}

Kata Kunci: Metabolit sekunder, antibakteri, daun sapat (Mitragyna speciosa Korth).

\section{ABSTRACT}

Research on Antibacterial Activity Test Sapat Leaf Extract (Mitragyna speciosa Korth.) of the bacterium Escherichia coli and Staphylococcus aureus. This research aims to determine the identification of secondary metabolites and antibacterial activity of methanolic extract of Sapat leaf (Mitragyna speciosa Korth.) against the bacteria Escherichia coli and Staphylococcus aureus. Identification of secondary metabolites is done by testing be qualitative. Antibacterial activity assays performed by agar diffusion method with a test concentration are $3 \%, 6 \%, 9 \%, 12 \%, 15 \%, 18 \%, 21 \%, 24 \%, 27 \%$ and $30 \%$. The results of identification of secondary metabolites are alkaloid, saponins, tannin, fenolic and steroid. Data has been analyzed with measuring the diameter of the kill zone of methanolic extract of Sapat leaf against bacterial growth. The result of research showed that methanolic extract of Sapat leaf produce radical zone. The effective concentration of methanolic extract of Sapat leaf was 24\% against the bacteria Escherichia coli and Staphylococcus aureus.

Keywords : Secondary metabolites, antibacterial, Mitragyna speciosa Korth.

\section{PENDAHULUAN}

Pengobatan penyakit yang disebabkan bakteri yang resisten terhadap antibiotik memerlukan senyawa baru yang memiliki potensi tinggi. Penelitian zat yang berkhasiat sebagai antibakteri perlu dilakukan untuk menemukan senyawa antibakteri baru yang berpotensi untuk menghambat atau membunuh bakteri yang resisten terhadap antibiotik 
dengan harga yang terjangkau. Salah satu alternatif yang dapat ditempuh adalah memanfaatkan zat aktif pembunuh bakteri yang terkandung dalam tanaman.

Staphylococcus aureus merupakan bakteri gram positif. Bakteri ini tumbuh secara anaerobik fakultatif dengan membentuk kumpulan sel-sel seperti buah anggur. Habitat bakteri ini adalah dikulit dan alat pernafasan dan umumnya ditemukan pada 20-50\% manusia sehat. Bakteri ini termasuk mesofil dengan suhu pertumbahan berkisar antara $37^{\circ} \mathrm{C}-48^{\circ} \mathrm{C}$. Nilai pH optimum adalah 6-7, $\mathrm{pH}$ minimum 4 dan $\mathrm{pH}$ maksimum 9,3-10.

Escherichia coli berbentuk batang, termasuk bakteri gram negatif. Bakteri ini bersifat anaerobik fakultatif. Escherichia coli pada umumnya merupakan flora normal yang terdapat pada pencernaan manusia dan hewan. Escherichia coli yang bukan merupakan flora normal, dapat menyebabkan diare pada bayi dan dapat mengakibatkan keracunan yang serius pada manusia.

Penelitian ini bertujuan untuk mengidentifikasi kandungan metabolit sekunder dan mengetahui aktivitas antibakteri dari ekstrak metanol daun sapat (Mitragyna speciosa Korth.) terhadap bakteri Escherichia coli dan Staphylococcus aureus.

\title{
METODE PENELITIAN
}

\begin{abstract}
Alat
Peralatan yang digunakan dalam penelitian ini antara lain bejana maserasi, rotary evaporator, timbangan analitik, cawan porselin, labu ukur, corong pisah, tabung reaksi, autoklaf, oven, inkubator, cawan petri, erlenmeyer, spoit injeksi dan alat penunjang lainnya.

\section{Bahan}

Bahan yang diteliti adalah simplisia daun sapat. Pelarut yang digunakan untuk ekstraksi adalah metanol. Bakteri uji yang digunakan adalah Escherichia coli dan Staphylococcus aureus. Medium yang digunakan adalah Nutrient Agar (NA). NaCl 0,9\% sebagai pensuspensi bakteri. Bahan kimia yang digunakan adalah asam klorida, kalium heksasianoferat (III), besi (III) klorida, asam asetat anhidrat, kloroform, asam sulfat, pereaksi Dragendorff dan pereaksi Mayer.
\end{abstract}

\section{PROSEDUR PENELITIAN}

\section{Pengumpulan dan Penyiapan Sampel}

Daun sapat diperoleh dari Kota Amuntai, Kalimantan Selatan. Daun sapat segar dikumpulkan kemudian disortasi basah. Setelah itu, daun sapat dicuci dan dikeringkan dengan cara diangin-anginkan didalam ruangan yang terlindung dari sinar matahari secara langsung. Selanjutnya daun sapat kering disortasi kering dan dipotong kecil-kecil menjadi serbuk simplisia.

\section{Ekstraksi}

Serbuk simplisia dimasukkan kedalam bejana maserasi dan dimaserasi menggunakan pelarut metanol. Proses ekstraksi dengan metode maserasi berlangsung selama kurang lebih 5 (lima) hari. Maserat (hasil maserasi) disaring menggunakan kertas saring dan ditampung kedalam wadah. Maserat kemudian dipekatkan menggunakan rotary evaporator dan dilanjutkan dengan penguapan di atas waterbath hingga diperoleh ekstrak metanol kental.

\section{Uji Metabolit Sekunder}

Identifikasi metabolit sekunder dilakukan pada ekstrak metanol. Uji identifikasi metabolit sekunder meliputi uji kandungan alkaloid, flavanoid, senyawa fenol, tanin, 
saponin, steroid dan triterpenoid. Pengujian dilakukan dengan menggunakan reagen yang berfungsi pada masing-masing kandungan senyawa kimia yang sesuai. Uji alkaloid menggunakan pereaksi Dragendorff dan pereaksi Mayer. Uji flavanoid menggunakan logam magnesium dan asam klorida. Uji senyawa fenol menggunakan larutan kalium heksasianoferat (III) dan besi (III) klorida. Uji tanin menggunakan larutan besi (III) klorida. Uji saponin menggunakan aquades dan asam klorida. Uji steroid dan triterpenoid menggunakan asam asetat anhidrat, kloroform dan asam sulfat.

\section{Pengujian Antibakteri}

Pengujian aktivitas antibakteri ekstrak daun sapat dilakukan dengan metode difusi agar dengan menggunakan medium NA. Suspensi bakteri dari pengenceran 1:40 sebanyak 0,02 $\mathrm{ml}$ dicampur dengan $10 \mathrm{ml}$ medium NA di dalam botol pengencer, digojog agar homogen kemudian dituang ke dalam cawan petri. Ditunggu hingga medium padat. Paperdisc dicelupkan di dalam larutan uji lalu diletakkan di atas permukaan medium NA yang telah padat, dan diinkubasi pada suhu $37{ }^{\circ} \mathrm{C}$ selama 24 jam. Kontrol negatif menggunakan paperdisc yang telah dicelupkan di dalam air suling.

\section{HASIL DAN PEMBAHASAN}

\section{Metabolit Sekunder}

Hasil identifikasi metabolit sekunder ekstrak metanol daun sapat maka diperoleh hasil positif yaitu golongan senyawa alkaloid, saponin, tanin, fenolik, steroid dan triterpenoid. Hasil uji metabolit sekunder dapat dilihat pada Tabel 1.

Tabel 1. Hasil Uji Metabolit Sekunder Ekstrak Metanol Daun Sapat

\begin{tabular}{lccccccc}
\hline \multirow{2}{*}{ Sampel Uji } & \multicolumn{7}{c}{ Metabolit Sekunder } \\
\cline { 2 - 7 } & Alkaloid & Flavonoid & Saponin & Tanin & Fenolik & Steroid & Triterpenoid \\
\hline Ekstrak Metanol & + & - & - & + & + & + & - \\
\hline Keterangan: & & & & & & \\
$(+)=$ terdeteksi metaolit sekunder & & & & & \\
$(-)=$ Tidak terdeteksi metabolit sekunder & & & &
\end{tabular}

Uji metabolit sekunder yang pertama yaitu uji alkaloid. Uji ini bertujuan untuk mengetahui adanya senyawa golongan alkaloid dengan menggunakan pereaksi warna Dragendorff. Hasil uji alkaloid yang telah dilakukan menghasilkan larutan dengan warna oranye yang apabila dibiarkan beberapa saat akan menghasilkan endapan berwarna oranye kecoklatan pada dasar tabung. Hal ini menunjukkan hasil positif untuk golongan alkaloid. Adanya senyawa golongan alkaloid ditunjukkan dengan adanya endapan berwarna oranye dengan pereaksi Dragendorff. Mekanisme kerja alkaloid sebagai antibakteri yaitu dengan cara mengganggu komponen penyusun peptidoglikan pada sel bakteri sehingga lapisan dinding sel tidak terbentuk secara utuh dan menyebabkan kematian sel tersebut. Mekanisme lain antibakteri alkaloid yaitu komponen alkaloid diketahui sebagai interkelator DNA dan menghambat enzim topoisomerase sel bakteri.

Uji metabolit sekunder yang selanjutnya yaitu uji flavonoid. Uji flavonoid dilakukan dengan menggunakan serbuk $\mathrm{Mg}$ dan $\mathrm{HCl}$ pekat. Hasil uji flavonoid dengan menggunakan uji warna menghasilkan larutan warna hijau, yang menandakan hasil negatif. Ekstrak kloroform sebagai ekstrak kasar masih banyak mengandung golongan-golongan senyawa 
yang kompleks sehingga kemungkinan menumpuknya senyawa pada saat dilakukan uji sangat besar.

Uji metabolit sekunder selanjutnya yaitu uji saponin. Hasil uji saponin tidak menghasilkan larutan dengan terbentuknya busa yang stabil setinggi $\pm 1 \mathrm{~cm}$, yang menandakan hasil negatif. Hal ini menandakan bahwa ekstrak metanol daun sapat tidak mengandung senyawa saponin.

Uji metabolit sekunder selanjutnya yaitu uji terpenoid dan steroid dengan menggunakan pereaksi Lieberman Burchard. Senyawa steroid ditunjukkan dengan terbentuknya warna hijau dan adanya senyawa terpenoid ditunjukkan dengan terbentuknya warna ungu.

Hasil penelitian yang diperoleh pada uji steroid menunjukkan hasil positif yang ditandai dengan terbentuknya perubahan warna dari kuning kehijauan menjadi hijau pekat, sedangkan pada uji terpenoid menunjukkan hasil negatif. Tidak terbentuknya warna merah keunguan pada uji warna kemungkinan bertumpuknya identifikasi senyawa metabolit sekunder serta uji aktivitas senyawa yang ada di dalam sampel masih sangat besar.

Steroid banyak terdapat di alam sebagai fraksi lipid dari tanaman atau hewan. Zat ini penting sebagai pengatur aktivitas biologis dalam organisme hidup. Steroid dibentuk oleh bahan alam yang disebut sterol. Sterol merupakan senyawa yang terdapat pada lapisan malam (lilin) daun dan buah yang berfungsi sebagai pelindung untuk menolak serangga dan serangan mikroba.

Uji metabolit sekunder yang berikutnya adalah uji fenolik dan uji tanin. Hasil uji fenolik dengan menggunakan uji warna menghasilkan larutan warna hijau kebiruan pekat, yang menandakan hasil positif. Sedangkan untuk tanin menghasilkan warna hijau kebiruan yang lebih pekat.

Tanin bekerja dengan cara mengendapkan protein dan dapat merusak membran sel sehingga pertumbuhan jamur terhambat. Senyawa tanin merupakan senyawa organik yang aktif menghambat pertumbuhan mikroba dengan mekanisme merusak dinding sel mikroba dan membentuk ikatan dengan protein fungsional sel mikroba. Mekanisme antibakteri yang dimiliki tanin yaitu kemampuannya menghambat sintesis khitin yang digunakan untuk pembentukan dinding sel pada jamur dan merusak membran sel sehingga pertumbuhan jamur terhambat. Tanin juga merupakan senyawa yang bersifat lipofilik sehingga mudah terikat pada dinding sel dan mengakibatkan kerusakan dinding sel.

\section{Aktivitas Antibakteri Ekstrak Daun Sapat}

Hasil uji aktivitas antibakteri menunjukkan bahwa ekstrak daun sapat memiliki aktivitas antibakteri terhadap bakteri Escherichia coli dan Staphylococcus aureus yang ditandai adanya zona bunuh di sekitar paperdisc. Kontrol negatif yaitu air suling tidak menghasilkan zona bunuh di sekitar paperdisc sehingga dapat dikatakan bahwa air suling tidak berpengaruh terhadap aktivitas antibakteri, hal ini membuktikan bahwa aktivitas antibakteri merupakan aktivitas dari ekstrak metanol daun sapat.

Pengujian aktivitas antibakteri ekstrak daun sapat terhadap bakteri Escherichia coli dan Staphylococcus aureus dilakukan dengan 10 (sepuluh) variasi konsentrasi yaitu 3\%, 6\%, $9 \%, 12 \%, 15 \%, 18 \%, 21 \%, 24 \%, 27 \%$ dan $30 \%$.

Zona bunuh yang terbentuk disekitar paperdisc yang diukur dengan menggunakan mikrometer skrup dapat dikategorikan sesuai kekuatan aktivitas antibakteri ekstrak metanol daun sapat. Kriteria suatu antibakteri dikatakan mempunyai aktivitas terhadap bakteri jika mempunyai ketentuan kekuatan sebagai berikut, luas daerah hambatan $20 \mathrm{~mm}$ atau lebih masuk kategori sangat kuat, daerah hambatan antara 10-20 mm masuk kategori kuat, daerah hambatan antara 5-10 $\mathrm{mm}$ masuk kategori sedang dan daerah hambatan $5 \mathrm{~mm}$ atau kurang 
masuk dalam kategori lemah. Data hasil pengukuran zona bunuh ekstrak metanol daun sapat dapat dilihat pada Tabel 2.

Tabel 2. Data aktivitas antibakteri ekstrak metanol daun sapat

\begin{tabular}{cccc}
\hline \multirow{2}{*}{ Sampel Uji } & Konsentrasi & \multicolumn{2}{c}{ Rerata Diameter Zona Bunuh (mm) } \\
\cline { 3 - 4 } & $(\boldsymbol{\%})$ & Escherichia coli & Staphylococcus aureus \\
\hline Ekstak Metanol & 3 & 0 & 0 \\
& 6 & 0 & 0 \\
& 9 & 6,28 & 5,87 \\
& 12 & 6,63 & 6,41 \\
& 15 & 7,24 & 6,83 \\
& 18 & 8,07 & 7,46 \\
& 21 & 9,46 & 8,15 \\
& 24 & 8,94 & 9,98 \\
& 27 & 8,53 & 8,88 \\
Kontrol Negatif & 30 & 0 & 8,49 \\
\hline
\end{tabular}

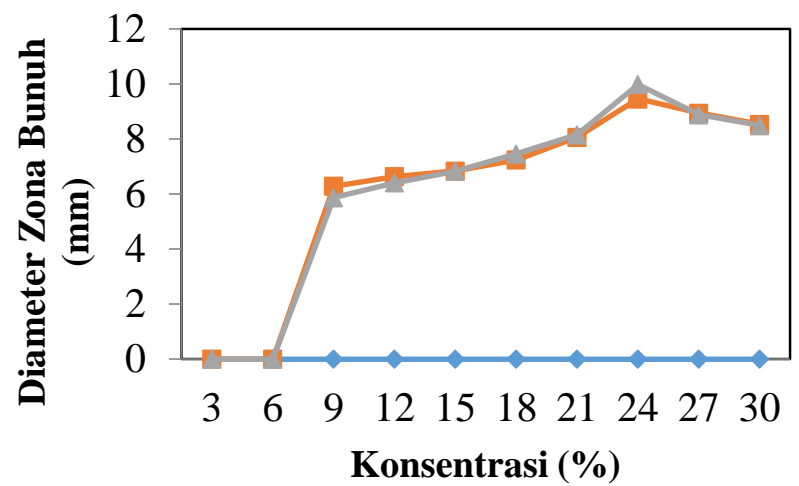

$\leadsto$ Kontrol Negatif

- Escherichia coli

- Staphylococcus

aureus

Gambar 1. Pengaruh konsentrasi ekstrak metanol daun sapat terhadap diameter zona bunuh bakteri Escherichia coli dan Staphylococcus aureus.

Tabel 2 menunjukkan bahwa daya aktivitas antibakteri ekstrak metanol daun sapat terhadap bakteri Escherichia coli dan Staphylococcus aureus pada konsentrasi 3\% dan 6\% tidak memiliki zona hambat maupun bunuh, pada konsentrasi 9\%, 12\%, 15\%, 18\%, 21\%, $27 \%$ dan $30 \%$ termasuk kategori sedang. Gambar 1. Merupakan kurva gravik perbandingan zona bunuh ekstrak metanol daun sapat terhadap bakteri Escherichia coli dan Staphylococcus aureus.

Gambar 1. menunjukkan adanya aktivitas antibakteri dari masing-masing konsentrasi ekstrak metanol daun sapat. Hal ini ditandai dengan adanya diameter zona bunuh yang diperoleh di setiap konsentrasi ekstrak metanol daun sapat. Dapat dilihat dari grafik bahwa titik puncak kenaikan aktivitas daya bunuh ekstrak metanol daun sapat terhadap bakteri Escherichia coli dan Staphylococcus aureus yaitu pada konsentrasi 24\%. Dilihat dari hasil diameter zona bunuh yang dihasil dari ekstrak metanol, yaitu meningkatnya konsentrasi uji ekstrak metanol dapat meningkatkan daya bunuh bakteri. Namun apabila konsentrasi uji dari ekstrak metanoldaun sapat terus ditingkatkan maka dapat terjadi penurunan daya bunuh. Hal ini dimungkinkan karena peningkatan konsentrasi menyebabkan viskositas dari ekstrak 
metanol daun sapat semakin meningkat, sehingga dapat mempengaruhi kecepatan difusi ekstrak tersebut dalam media agar.

Konsentrasi efektif ekstrak metanol daun sapat adaah konsentrasi terendah yang memberikan kemampuan terbaik dalam membunuh bakteri. Konsentrasi efektif ditandai dengan luas diameter zona bunuh terbesar dari aktivitas antibakteri ekstrak metanol daun sapat. Data aktivitas antibakteri dianalisis menggunakan Anava sat arah dan uji lanjutan Beda Nyata Jujur Duncan (BNJD). Hasil konsentrasi efektif ekstrak metanol daun sapat terhadap bakteri Escherichia coli dan Staphylococcus aureus dapat dilihat pada Tabel 3.

Tabel 3. Konsentrasi efektif ekstrak metanol daun sapat

\begin{tabular}{ccc}
\hline Bakteri Uji & $\begin{array}{c}\text { Konsentrasi Efektif } \\
(\mathbf{\%})\end{array}$ & $\begin{array}{c}\text { Diameter Zona Bunuh } \\
(\mathbf{m m})\end{array}$ \\
\hline Escherichia coli & 24 & 9,46 \\
Staphylococcus aureus & 24 & 9,98 \\
\hline
\end{tabular}

Tabel 3. menunjukkan bahwa konsentrasi efektif ekstrak metanol daun sapat dapat membunuh bakteri Escherichia coli dan Staphylococcus aureus adalah konsentrasi 24\% dengan diameter zona bunuh terbesar dibandingkan dengan konsentrasi-konsentrasi uji lainnya yaitu $9,46 \mathrm{~mm}$ dan $9,98 \mathrm{~mm}$.

Menurut Ajizah (2004), selain faktor konsentrasi, jenis bahan antimikroba yang dihasilkan juga menentukan kemampuan menghambat pertumbuhan bakteri. Dalam penelitian ini, aktivitas antibakteri daun sapat diduga karena adanya kandungan senyawasenyawa berkhasiat, seperti alkaloid, fenolik, tannin, saponin, steroid dan triterpenoid.Menurut de-Fatima et al.,2006 senyawa alkaloid diketahui bersifat antimikroba terhadap bakteri, fungi, virus dan protozoa. Mekanisme antimikroba senyawa alkaloid terlibat dalam perusakan membran sel oleh senyawa lipofilik.

\section{KESIMPULAN}

Berdasarkan penelitian yang telah dilakukan, dapat diperoleh kesimpulan sebagai berikut:

1. Kandungan metabolit sekunder dari ekstrak metanol daun sapat (Mitragyna speciosa Korth) adalah senyawa golongan alkaloid, saponin, tannin, fenolik, steroid dan triterpenoid.

2. Ekstrak metanol daun sapat (Mitragyna speciosa Korth.) memiliki aktivitas antibakteri terhadap bakteri Escherichia coli dan Staphylococcus aureus.

3. Konsentrasi efektif ekstrak metanol (Mitragyna speciosa Korth.) untuk bakteri Escherichia coli dan Staphylococcus aureus yaitu $24 \%$.

\section{DAFTAR PUSTAKA}

Ajizah, A. 2004. Sensitivitas Salmonella typhimurium terhadap ekstrak daun Psidium guajava. J Bioscientiae. 1(1):31-38

Djide dan Sartini. 2008. Dasar-dasar Mikrobiologi Farmasi. Lephas. Makassar.

de-Fatima, A., L. V. Madolo, L. S. Conegero, R. A. Pilli, C. V. Ferreira, L. K.Kohn, and J. E. de-Carvalho. 2006. Lactones and their derivatives: biological activities, mechanisms of action and potential leads for drugs design. Journal Medical Chemistry. (13): 3371-3384. 
Harborne, J. B. 2006. Metode Fitokimia. Penerbit ITB: Bandung.

Irianto, Koes. 2013. Mikrobiologi Medis. Penerbit Alfabeta: Bandung. 